\title{
Injuries Associated with Underground Coal Mining Equipment in Australia
}

\author{
Robin Burgess-Limerick*
}

Minerals Industry Safety and Health Centre, Sustainable Minerals Institute, The University of Queensland, Australia

\begin{abstract}
In the 3 years to June 30, 2008, 4,633 injuries occurring underground at NSW (Australia) coal mines were reported to the insurer. Equipment was involved in 2149 of these injuries (46\%). The narrative field accompanying these reports was examined to determine opportunities for controlling injury risks. The most common equipment types involved were: Continuous miner (12\% of all underground injuries); Bolting machines (6\%); LHD (8\%); Longwall (7\%); Personnel Transport (4\%); and Shuttle Car (3\%). The most common combinations of equipment and mechanism were: strains while handling items associated with continuous miner or bolting machines; strains, or being struck by, or caught between, while drilling or bolting on a continuous miner or bolting machine; driving or traveling over rough roads in a variety of equipment; being struck by while operating Longwall equipment. Rare, but high potential consequence events reported during the period included: interactions between personnel and mobile equipment; interactions between personnel and Longwall shield movements; transport equipment collisions. A range of potential short-term control measures for these risks have been identified, including monorails for continuous miner services; redesign of continuous miner platforms and bolting rigs to reduce reach distances during drilling and bolting; improvements to guarding of bolting controls; standardisation and shape coding of bolting controls; two handed fast-speed drilling \& bolting; improvements in underground roadway maintenance, vehicle suspension, visibility and seating; and proximity detection devices interlocked with mobile equipment controls. Longer term control measures include automated bolting, and mesh placement, in conjunction with either non-line-of-sight remote control of, or automated, continuous mining machines.
\end{abstract}

Keywords: Occupational injuries, underground coal mining, mining equipment, narratives text analysis, continuous miner, shuttle car, bolting.

\section{INTRODUCTION}

Working with or near underground coal mining equipment is inherently hazardous due to the multiple sources of injurious energies and adverse environmental conditions. Australian coal mines are acknowledged as having excellent safety records. This has been ascribed, at least in part, to the risk based regulatory framework under which the mines operate [1]. As indicated in Table 1, the rate of injuries involving lost time decreased considerably in New South Wales mines over the 8 years to the end of June 2006 , and remained relatively constant over the next two years. Australian compensation statistics suggest that $22 \%$ of all lost time claims in the mining industry are associated with mobile plant and transport [2]. The aim of this investigation is to examine narratives describing equipment related injuries occurring at NSW underground coal mines as a means of identifying opportunities for further reducing injury risks.

A previous analyses of injuries associated with a subset of underground coal mining equipment types has been reported [3]. This paper extends the analysis to include all equipment types, and utilises data from the three years to the end of June, 2008. During this period in NSW there were between 29 and 30 operating underground coal mines, predominantly Longwall mines operated by large companies. The number of employees during the period increased from

*Address correspondence to this author at the Minerals Industry Safety and Health Centre, Sustainable Minerals Institute, The University of Queensland, 4072 Australia; Tel +61 73366 4084;

E-mail: r.burgesslimerick@uq.edu.au
6541 to 7030 , with raw production increasing from 52.2 to 60.6 million tonnes per annum (Table $\mathbf{1}$ ).

Conventional analyses of injury statistics typically provide tables detailing the breakdown of injuries by body part, nature of injury, mechanism of injury, or agency of injury. Such analyses are appropriate and may especially be helpful in tracking broad trends over time, however further, and perhaps more valuable, information is available in the narrative text field completed for each injury reported to the workers' compensation insurer for coal mines in NSW (Coal Services Pty Limited). The detail contained in these narratives varies, however additional insight is generally into the causes of the injury, such as the activity being performed at the time of the injury. Analysis of injury narratives has previously been undertaken in mining [3-5]; construction [68]; welders [9] and truck drivers [10].

Helander and Krohn [4], for example, conducted an analysis of injury narratives for most hazardous underground machinery in hard rock mining, coding the narratives for worker activity, suggested cause of accident; machine part involved, and body part injured. Similarly, Helander et al. [5] examined injury narratives from 600 roof-bolter accident reports from mines in the USA and coded each for cause, machine part, and body part injured; concluding that roof bolting was the most dangerous job in US underground coal mines and that rock falls accounted for $25 \%$ of roof bolting injuries.

The information available in injury narratives has potential to aid in prioritising effective control measures. The aim of the analysis was to utilise injury narratives to 
Table 1. NSW Underground Coal Mining Statistics 97/98 to 07/08

\begin{tabular}{|c|c|c|c|c|c|c|c|c|c|c|c|}
\hline Financial Year & $97-98$ & $98-99$ & $99-00$ & 00-01 & 01-02 & $02-03$ & 03-04 & $04-05$ & $05-06$ & $06-07$ & $07-08$ \\
\hline Number of miners & 6957 & 6063 & 5615 & 5737 & 5497 & 5064 & 5054 & 5620 & 6541 & 6792 & 7030 \\
\hline Raw production (million tonnes) & $\mathrm{n} / \mathrm{a}$ & $\mathrm{n} / \mathrm{a}$ & $\mathrm{n} / \mathrm{a}$ & $\mathrm{n} / \mathrm{a}$ & $\mathrm{n} / \mathrm{a}$ & 46.9 & 49.3 & 51.9 & 52.2 & 57.2 & 60.6 \\
\hline Fatalities & 1 & 2 & 3 & 2 & 1 & 0 & 2 & 0 & 0 & 1 & 0 \\
\hline Serious injuries & $\mathrm{n} / \mathrm{a}$ & $\mathrm{n} / \mathrm{a}$ & 26 & 34 & 27 & 26 & 43 & 25 & 24 & 27 & 18 \\
\hline
\end{tabular}

Source: NSW Minerals Council Key Industry Statistics 2008. (www.nswmin.com.au).

identify opportunities for reducing common injury risks associated with underground coal mining equipment. Consideration of frequency alone fails to draw attention to low probability, but potentially high consequence, injury risks. Such "sentinel" events were also identified within the injury narratives and highlighted within the results.

\section{METHODS}

Coal Services Pty Ltd, is the sole workers' compensation insurer for NSW coal mines. De-identified narrative text fields for all incidents reported by underground coal mines in New South Wales during the 3 years to June 30, 2008 were obtained from Coal Services Pty Ltd. These reports included injuries of varying severity, from medical expenses only, to time lost, and serious bodily injury. Narratives describing the injuries occurring underground were manually coded for equipment involvement; activity being undertaken by the injured person immediately prior to the injury; the injury mechanism; and agent of injury, using previously determined codes [3]. Frequencies of cross-tabulated combinations of codes were calculated and presented graphically to aid interpretation. Examples of injury narratives are also provided.

\section{RESULTS}

The total number of injuries reported by underground coal mines to Coal Services Pty Ltd in the 3 years to June 30, 2008 was 4633 (excludes injuries occurring on the surface at an underground mine, as well as hearing loss claims). Equipment was involved in 2149 of these injuries (46\%). The most common equipment types involved were: Continuous miner $(555,12 \%)$; Bolting machines $(257,6 \%)$; LHD (351, 8\%); Longwall (332, 7\%); Transport (194, 4\%);
Shuttle Car (152, 3\%). Other equipment involved in the remaining 308 injuries included hand-held bolters (115), and a variety of other equipment such as graders, stone dusting equipment, dolly cars, road headers, longwall move equipment, and gas drainage drilling equipment.

\subsection{Continuous Mining/Bolting Machine}

Continuous miner and bolting machines were grouped for subsequent analysis. Table 2 provides a breakdown of the number of injuries by activity and mechanism. These data are illustrated in Fig. (1). Consideration of the data presented in Table 2 and Fig. (1) reveals that injuries most frequently occurred whilst miners were drilling and bolting, and handling bolting supplies such as drill steels, bolts and mesh. Common injury mechanisms associated with drilling and bolting included: striking part of the equipment, or being struck by falling objects such as steels, bolts, plates, or material from the roof or rib, or hydraulic fluid (31 instances); strain; and some part of the person between caught between moving parts of the equipment. Handling a variety of objects including bolting supplies, and especially cable, was associated with strains of various body parts. Maintenance and access to the operating platform, were also relatively common activities. Examples of each of these injury types are provided in Table 3 . Infrequent, but potentially high consequence events associated with miners and bolters included:

"While operating c/miner filling a s/car rib fell pushing him into the s/car bruising his lower back" and

"While he was walking past left side of $\mathrm{c} /$ miner it turned forcing him into rib jamming him between the c/miner \& rib bruising 1/thigh".

Table 2. Underground Injury Frequency by Activity and Mechanism for Continuous Miner and Bolting Machines

\begin{tabular}{|c|c|c|c|c|c|c|}
\hline Access & 0 & 16 & 41 & 12 & 1 & 70 \\
\hline Handling & 8 & 18 & 176 & 34 & 1 & 237 \\
\hline Maintenance & 10 & 12 & 34 & 37 & 1 & 94 \\
\hline Other & 2 & 5 & 6 & 10 & 1 & 24 \\
\hline Total & 93 & 76 & 331 & 304 & 8 & 812 \\
\hline
\end{tabular}




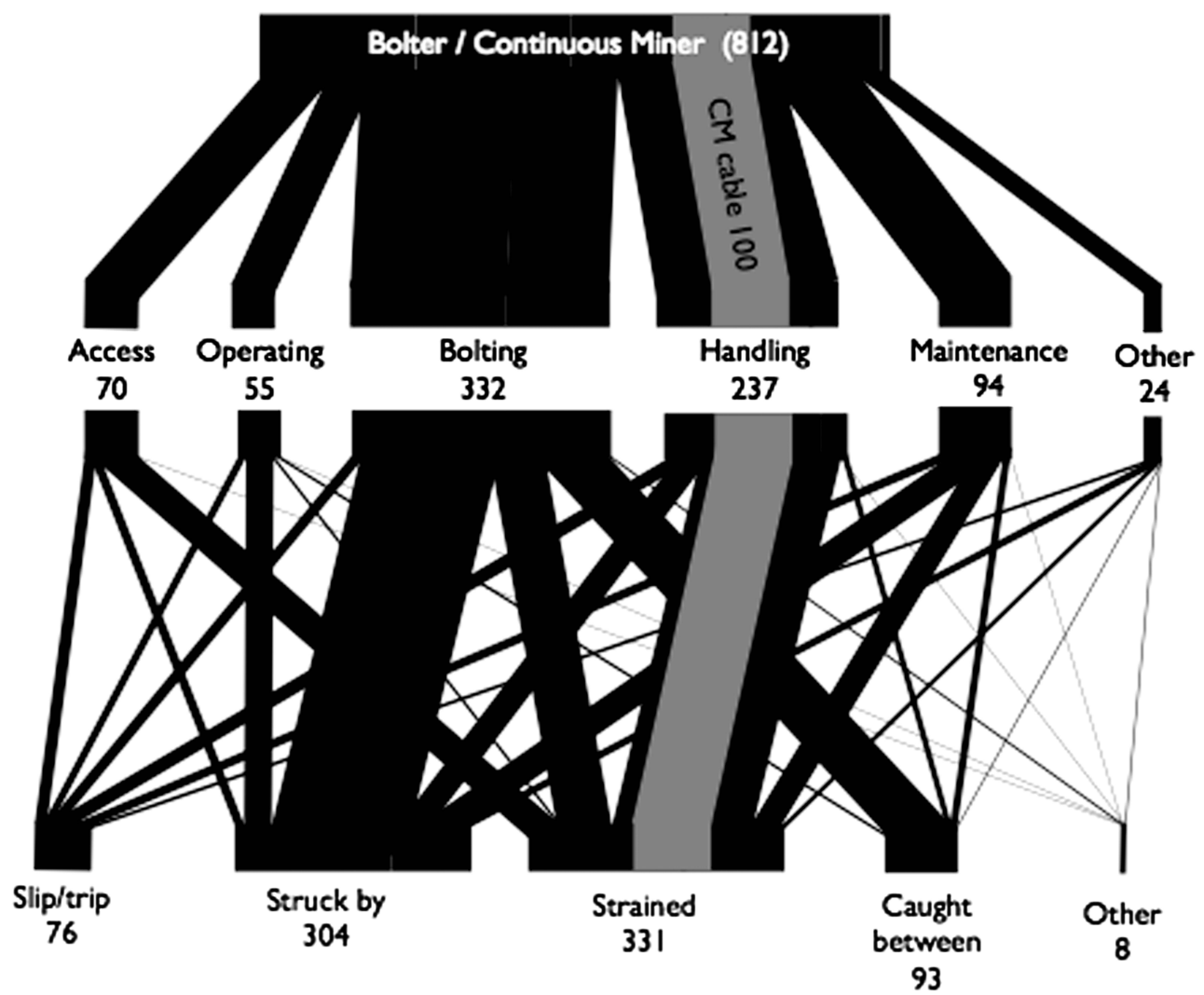

Fig. (1). Underground injury frequency by Activity and Mechanism for Continuous Miner and Bolting Machine for NSW mines during the 3 years to June $30,2008$.

\subsection{Load-Haul-Dump}

Table 4 provides the frequency of injuries for each combination of activity and mechanism for injuries associated with Load-Haul-Dump (LHD) equipment. Fig. (2) presents these same data graphically. Consideration of these data reveals that injuries most frequently occurred to the drivers of LHDs, and that the most frequent injury mechanisms were associated with rough roads, being struck by, and ran into. The next most frequent activity being performed at the time of injury was access to, and particularly, egress from LHDs in which case slips/trips, and strains were relatively common injury mechanisms. Examples of injury narratives are provided in Table $\mathbf{5}$. Infrequent, but potentially high consequence events associated with LHD included:

"He was at the hydrant washing $\mathrm{c} / \mathrm{m}$ remote when a front loader heading outbye suddenly came back inbye and ran into him spun him around the wheel passed over his lower leg and fractured L/tibia"

"While standing behind Eimco observing the gear being unloaded the Eimco reversed \& pinned him between work platform \& bucket spraining his L/ankle", and

"While reversing Eimco pushing power tram he stood up to see where he was going his head got caught between the machine \& gas drainage pipe causing closed head injury".

\subsection{Longwall}

Injuries associated with Longwall equipment are presented in Table $\mathbf{6}$ and Fig. (3). Consideration of these data reveals that injuries associated with Longwall equipment most frequently occurred during operation, maintenance and walking on the face, and that the most frequent injury mechanism was being struck by, typically by coal or rock from the roof or face, but also by hydraulic oil (57 instances), and also including striking the head on the Longwall supports. Slipping or tripping was also relatively frequent. Examples of injury narratives are provided in Table 7. Infrequent, but potentially high consequence events associated with Longwall included:

"When operating shearer he slipped on a cobble of coal on 116 chock which started to advance catching him between a chock \& pantech causing fractured pelvis \& ruptured bladder",

"While setting up for maintenance a longwall support advanced knocking him over pinning his $\mathrm{R} /$ lower leg causing puncture wound medial right ankle \& bruised calf", and

"While advancing chock his L/foot was caught underneath a shield causing amputation of his $\mathrm{L} / 2$ nd and $\mathrm{L} / 3$ rd toes"

\subsection{Transport}

Injuries associated with personnel transport are presented in Table 8 and Fig. (4). Consideration of these data reveals 
Table 3. Example Injury Narratives for the Most Frequent Combinations of Activity and Mechanism Associated with Continuous Miners and Bolting Machines

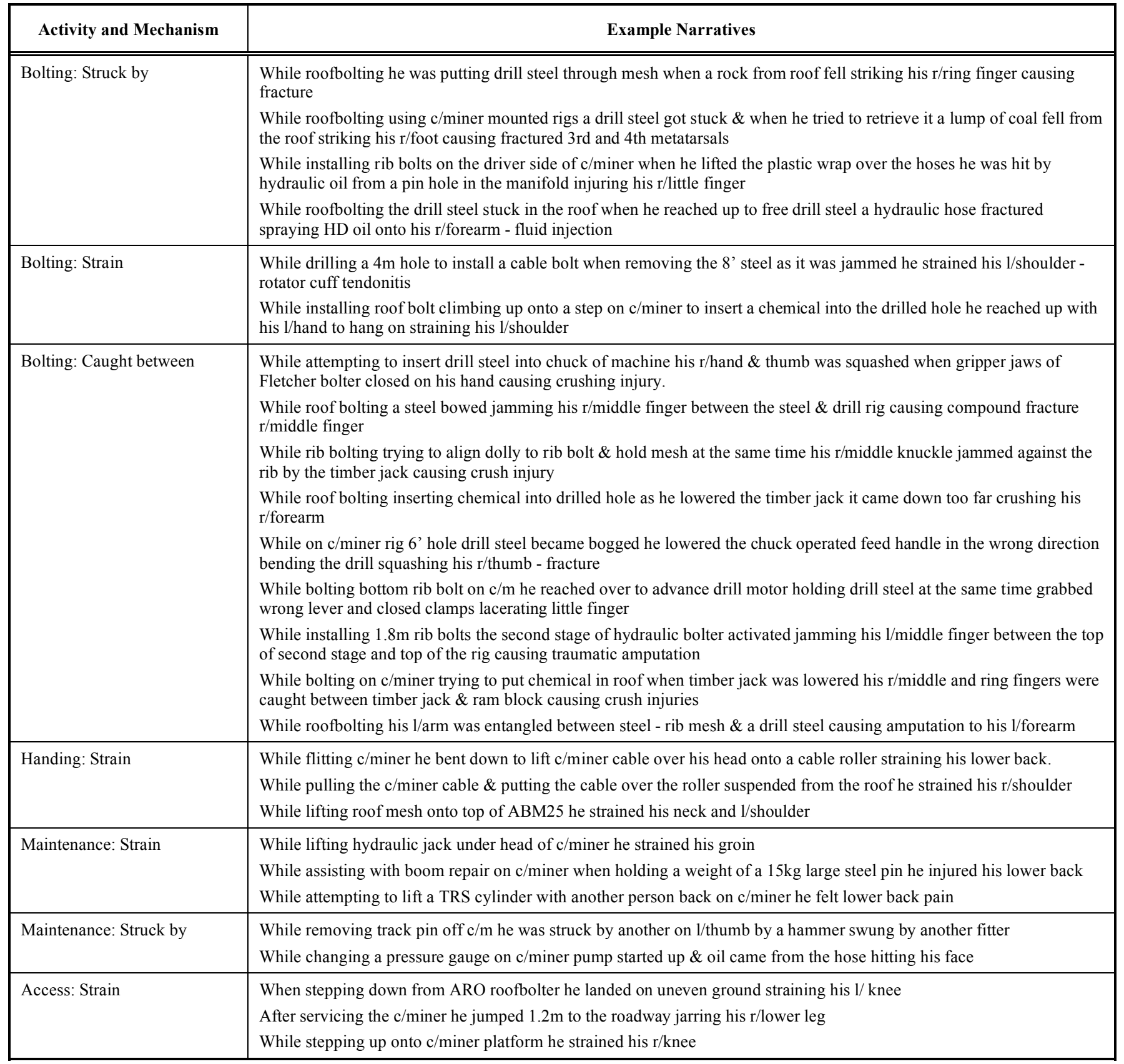

that injuries associated with personnel transport most frequently occurred to passengers as a consequence of traveling over rough roads. Injuries also occurred during access. Examples of injury narratives are provided in Table 9. Infrequent, but potentially high consequence events associated with transport included:

"While travelling in transported it ran into back of another transporter causing him to hit his $\mathrm{L} / \mathrm{knee}$ on the steel wall of engine compartment" and

"While being transported out of pit driver fell asleep \& crashed PJB into rib \& got thrown into steel canister spraining his neck".

\subsection{Shuttle Car}

Injuries associated with the operation of shuttle cars are described in Table $\mathbf{1 0}$ and Fig. (5). Consideration of the data presented in Table $\mathbf{1 0}$ and Fig. (5) reveals that injuries associated with shuttle cars most frequently occurred to drivers as a consequence of traveling over rough roads or being struck by. Injuries also occurred during maintenance. Examples of injury narratives are provided in Table 11. Infrequent, but potentially high consequence events associated with shuttle cars included:

"While working as a cable hand on c/miner he turned to see a s/car approaching he slipped into s/car wheel rut \& L/foot was run over by s/car causing crush injury" 
Table 4. Underground Injury Frequency by Activity and Mechanism Associated with Load-Haul-Dump Equipment

\begin{tabular}{|c|c|c|c|c|c|c|c|c|}
\hline & Caught Between & Ran into & Rough Road & Slip/Trip & Strain & Struck by & Other & Total \\
\hline Access & 7 & 0 & 0 & 21 & 44 & 9 & 0 & 81 \\
\hline Driving & 8 & 18 & 69 & 0 & 12 & 46 & 1 & 154 \\
\hline Handling & 18 & 0 & 0 & 3 & 35 & 12 & 0 & 68 \\
\hline Maintenance & 3 & 0 & 0 & 2 & 8 & 14 & 3 & 30 \\
\hline Other & 9 & 2 & 0 & 1 & 0 & 6 & 0 & 18 \\
\hline Total & 45 & 20 & 69 & 27 & 99 & 87 & 4 & 351 \\
\hline
\end{tabular}

Table 5. Example Injury Narratives for the Most Frequent Combinations of Activity and Mechanism Associated with LHDs

\begin{tabular}{|c|c|}
\hline Activity and Mechanism & Example Narratives \\
\hline Driving: Rough road & $\begin{array}{l}\text { While driving Eimco hit a big hole in road seat bottomed out jarring his neck and lower back } \\
\text { While driving Eimco struck holes at } 20 \mathrm{CT} \text { MG } 23 \text { causing him to strike his head on roll bar causing neck pain } \\
\text { While driving an Eimco outbye to pick up a bucket machine hit a piece of timber on the road straining his neck \& } \\
\text { lower back. }\end{array}$ \\
\hline Driving: Struck by & $\begin{array}{l}\text { While driving Eimco mucking out cut through a piece of rib struck his 1/ring finger - amputation } \\
\text { While driving Eimco LHD under pipe range the pipes fell over on back of cab \& slipped off hitting his head } \\
\text { jarring his neck and 1/shoulder } \\
\text { While driving Eimco with } 11 \text { mesh modules on the top mesh caught on a roof bolt causing the mesh to swing } \\
\text { around \& strike his r/cheek causing laceration. }\end{array}$ \\
\hline Driving: Ran into & $\begin{array}{l}\text { While driving Eimco he hit his head on a roof bolt injuring his neck } \\
\text { While driving LHD Eimco past a parked Eimco a forklift tyne from parked Eimco entered the drivers cab crushing } \\
\text { the first three toes on his r/foot } \\
\text { While driving Eimco out of } 940 \text { run into bolting pods that were side by side in the rib making LHD bounce and } \\
\text { jarred his lower back. }\end{array}$ \\
\hline Access: Strain & $\begin{array}{l}\text { While hopping out of Eimco } 913 \text { battery cord caught door handle pulling his head back quickly and straining his } \\
\text { neck } \\
\text { While hopping out of Eimco cab he twisted to get out and stepped down straining his lower back } \\
\text { When he stepped out of Eimco he rolled his 1/ankle causing sprain }\end{array}$ \\
\hline Access: Slip/trip & While getting on Eimco he slipped under the brake pedal and fell over straining his $r / k n e e$ \\
\hline
\end{tabular}

"While training to drive s/car from bootend to c/miner he was crushed between the s/car \& the rib causing crush injury to his $1 /$ hand"

"While standing in the rib as a s/car was passing he slipped on loose surface his $r /$ foot went under s/car wheel causing bruising".

\section{DISCUSSION}

The most common injuries associated with underground coal equipment in NSW in the 3 years to June 30, 2008 were: strains while handling items associated with continuous miner or bolting machines (176 injuries) or while drilling or bolting on continuous miner or bolting machine (70 injuries); injuries involving being struck by, or caught between, while drilling or bolting on continuous miner or bolting machine (175 injuries and 69 injuries); injuries occurring while driving or traveling over rough roads in a variety of equipment such as LHD, shuttle car and transport (164 injuries); and injuries arising as a consequence of being struck by falling rock or other material while operating Longwall equipment (98 injuries). While the majority of the injuries documented in these narratives are relatively minor, the potential for serious injuries and fatalities is ever present, particularly when large mining equipment is operating in close proximity to people.

Continuous mining and bolting machines are powered by long and very heavy trailing electrical cables. One common cause of strains associated with these equipment is the manual handling of cables. The severity of injuries associated with handling cable varies from relatively minor shoulder strains to serious back injuries. Whilst the cumulative nature of most musculoskeletal injuries implies 


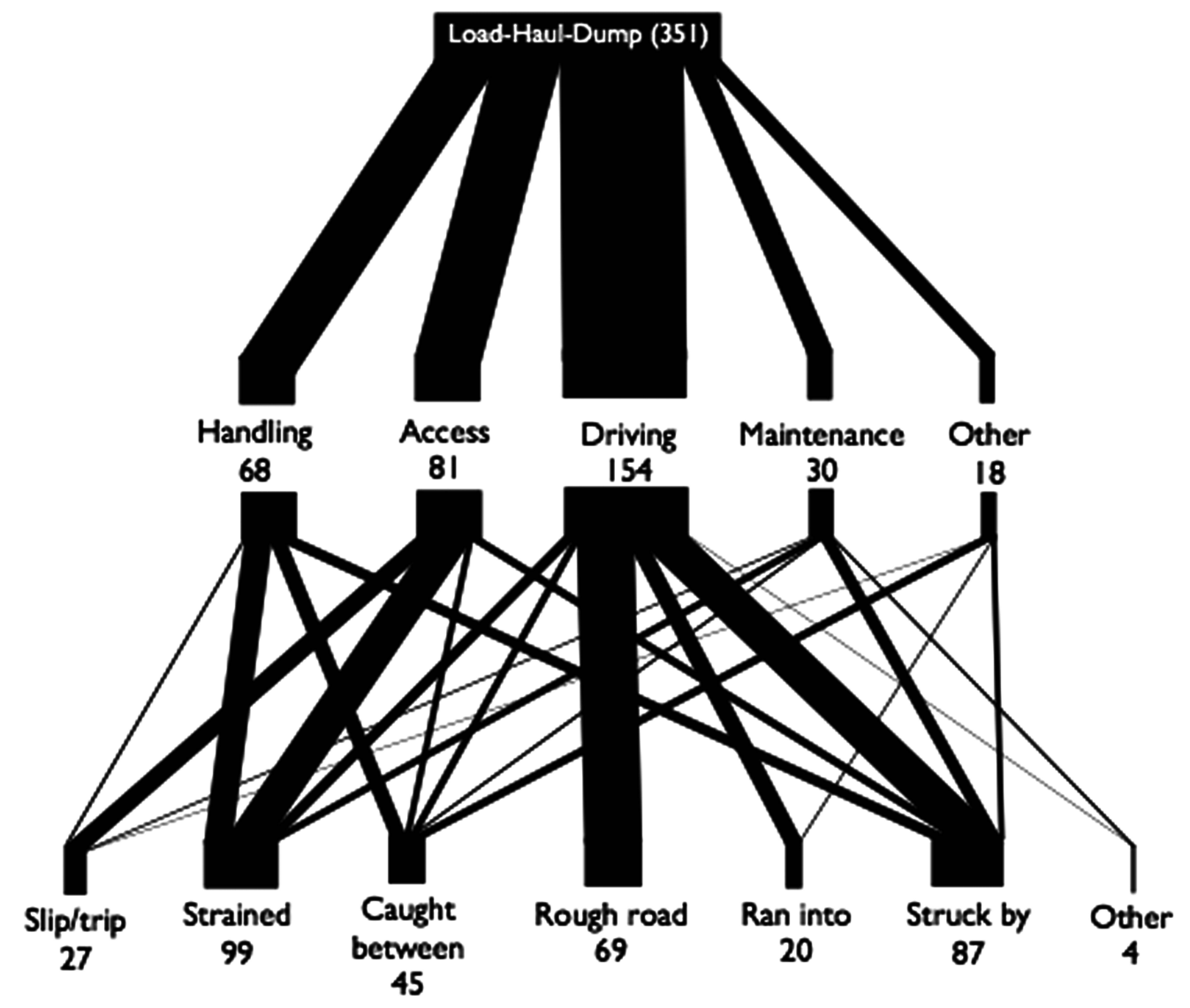

Fig. (2). Underground injury frequency by Activity and Mechanism associated with LHD for NSW mines during the 3 years to June 30 , 2008.

Table 6. Underground Injury Frequency by Activity and Mechanism for Longwall Equipment

\begin{tabular}{|c|c|c|c|c|c|c|}
\hline & Caught Between & Slip/Trip & Strain & Struck by & Other & Total \\
\hline Access & 0 & 9 & 10 & 5 & 0 & 24 \\
\hline Walking & 0 & 26 & 3 & 24 & 0 & 53 \\
\hline Handling & 2 & 15 & 18 & 3 & 0 & 38 \\
\hline Maintenance & 11 & 12 & 15 & 39 & 1 & 78 \\
\hline Operating & 4 & 17 & 1 & 98 & 1 & 121 \\
\hline Other & 2 & 4 & 0 & 12 & 0 & 18 \\
\hline Total & 19 & 83 & 47 & 181 & 2 & 332 \\
\hline
\end{tabular}

that other manual tasks are likely to have also contributed to these injuries, there is no doubt that that handling continuous miner cable represents a high risk of injury, and this is consistent with biomechanical analysis of the task [11]. Engineering controls are required to eliminate or reduce manual cable handling. One control which has been developed to reduce the requirement to manually handle continuous miner cables is the installation of a monorail to which services, including electrical cables are fastened. Additional sections of monorail are added as the continuous miner advances. This control measure has great potential to reduce injury risks, and is beginning to be adopted in Australian mines.
Handling of drilling and bolting supplies, and roof support mesh, is a second common cause of strain injuries, although loading supplies (bolts, resin, plates) onto pods on the surface and loading these via mobile plant has become more common. Manual handling of the supplies and drill steels, is still undertaken during the drilling and bolting process itself however, and the prolonged and repeated performance of a task which commonly involves awkward shoulder postures to place drill steels and bolting in a chuck located at some distance from the miner's body is, unsurprisingly, associated with musculoskeletal injuries to the back, shoulder, and wrist. More recent designs of bolting workstations have been successful in reducing the reach distances required (and thus the shoulder loads), however, the risk will remain as long as drilling and bolting is 
Table 7. Example Injury Narratives for the Most Frequent Combinations of Activity and Mechanism Associated with Longwall Equipment

\begin{tabular}{|c|c|}
\hline Activity and Mechanism & Example Narratives \\
\hline Operating: Struck by & $\begin{array}{l}\text { While operating shearer cutting towards the TG he was struck on his L/ear by fly rock causing laceration } \\
\text { While operating shearer a piece of rock flew from shearer \& struck his chest causing him to fall between supports straining } \\
\text { his R/shoulder \& injured chest and back } \\
\text { While he was activating shield a lump of stone fell between shield striking his hand causing a fracture } \\
\text { While operating } 18 \text { roof support with } 17 \text { roof support mimic he walked on } 18 \text { roof support \& a hose burst spraying oil on his } \\
\text { R/thigh causing high pressure injury } \\
\text { While operating hydraulic directional control valve on } 92 \mathrm{~L} / \mathrm{W} \text { shield to retract DA RAM a hose retaining staple worked loose } \\
\text { releasing valve bank causing pressurized hydraulic fluid to release hitting his L/thigh }\end{array}$ \\
\hline Maintenance: Struck by & $\begin{array}{l}\text { While changing picks on shearer in LW407 a slab of coal fell and smashed his L/leg causing fracture } \\
\text { While adjusting BSL chain when high pressure fitting blew out and fluid wet his leg \& pressure hit his bottom - possible high } \\
\text { pressure fluid injection }\end{array}$ \\
\hline Walking: Struck by & $\begin{array}{l}\text { While walking along } \mathrm{L} / \mathrm{W} \text { face he struck his head on a chock \& fell backwards straining his neck } \\
\text { While walking past chock a high pressure fitting blew out spraying him with emulsion bruising legs trunk \& head }\end{array}$ \\
\hline Walking: Slip/Trip & $\begin{array}{l}\text { While walking along pontoons of shields from } \mathrm{T} / \mathrm{G} \text { to } \mathrm{M} / \mathrm{G} \text { he slipped off the pontoon twisting his knee } \\
\text { While walking along } \mathrm{LW} \text { face his foot slipped between chock feet \& rolled over on his R/ankle causing sprain }\end{array}$ \\
\hline Operation: Slip/Trip & While operating L/W shearer he slipped on the chock pontoon straining his lower back \\
\hline Maintenance: Slip/Trip & $\begin{array}{l}\text { While assisting to clean out cable tray he slipped \& fell backwards when his L/leg was caught between chock leg and baselift } \\
\text { RAM injuring his L/knee - medial ligament tear } \\
\text { While standing on pontoon of a chock he was using a pinch bar to lever a hose the bar slipped causing him to fall backwards } \\
\& \text { strike his head on cable tray of AFC jarring his neck \& felt pain to his shoulder \& lower back }\end{array}$ \\
\hline
\end{tabular}

undertaken manually. Considerable efforts are underway to achieve automated bolting [12] and marked injury reductions in musculoskeletal injuries are anticipated when this is achieved and implemented widely. The handling of mesh will simultaneously be replaced by an automated manipulator, or replaced with a spray on polymer [13].

Another serious injury risk which arises as a consequence of the current manual drilling and bolting procedures is the risk associated with being struck by or caught between the moving equipment components. Some injuries occur as a consequence of inadvertent operation of drilling/bolting controls while the operator or another person is in a hazardous position. This can occur, for example, by rock or rib, or drill steel, falling onto an unguarded control; another common cause of inadvertent control operation is a miners' self-rescuer, or cap lamp cord bumping or catching on a control lever. Additional guarding is being employed by designers to reduce this risk.

Other bolting related injuries are attributable to an operator making either a control selection error (where the incorrect control is operated); or a direction error (where the correct control is operated, but in the incorrect direction). Standardisation of mining equipment controls, especially drilling and bolting controls, and the use of shape and length coding has been suggested on numerous occasions over the past 40 years as a means of addressing perceived inadequacies [14-18]. (Hedling \& Folley, 1972; Grayson et al., 1992; Helander et al., 1980; Klishis et al., 1993; Muldoon et al., 1980).

In 1972, Hedling and Folley [14] noted (in the context of continuous miner controls) that "the widespread use of traditional round control knobs regardless of function being controlled is another source of error in operation" and proposed that "Each control knob is designed to resemble (at least symbolically) the equipment it represents". Similarly, Helander et al. [16] suggested in the context of bolting machines that "poor human factors principles in the design and placement of controls and inappropriately designed workstations contribute to a large percentage of the reported injuries" (p. 18). In particular, a lack of standardisation of controls was noted, with more than 25 different control sequences being identified, differences existing even on similar machines produced by the same manufacturer. Helander et al. also noted the lack of control coding, violation of direction stereotypes, a mixture mirror image and left/right arrangements, and the possibility of inadvertent operation. Klishis et al. [17] made similar observations 10 years later, noting a lack of standardisation even among machines from the same manufacturer and commenting on the potential for operating the wrong control. Evidence for the potential effectiveness of shape coding in reducing selection errors some circumstances has recently been provided [19]. 


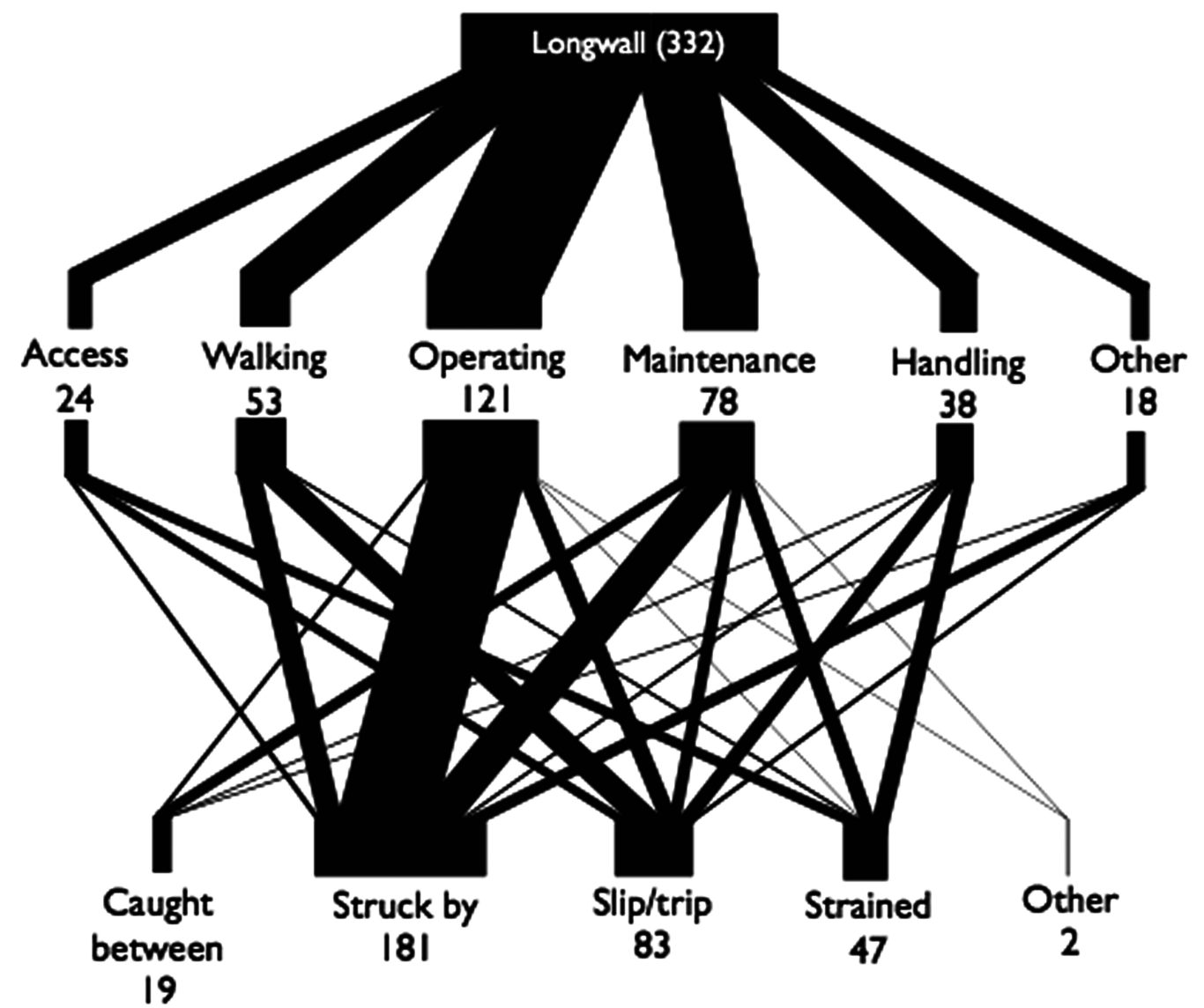

Fig. (3). Underground injury frequency by Activity and Mechanism associated with Longwall equipment for NSW mines during the 3 years to June 30, 2008.

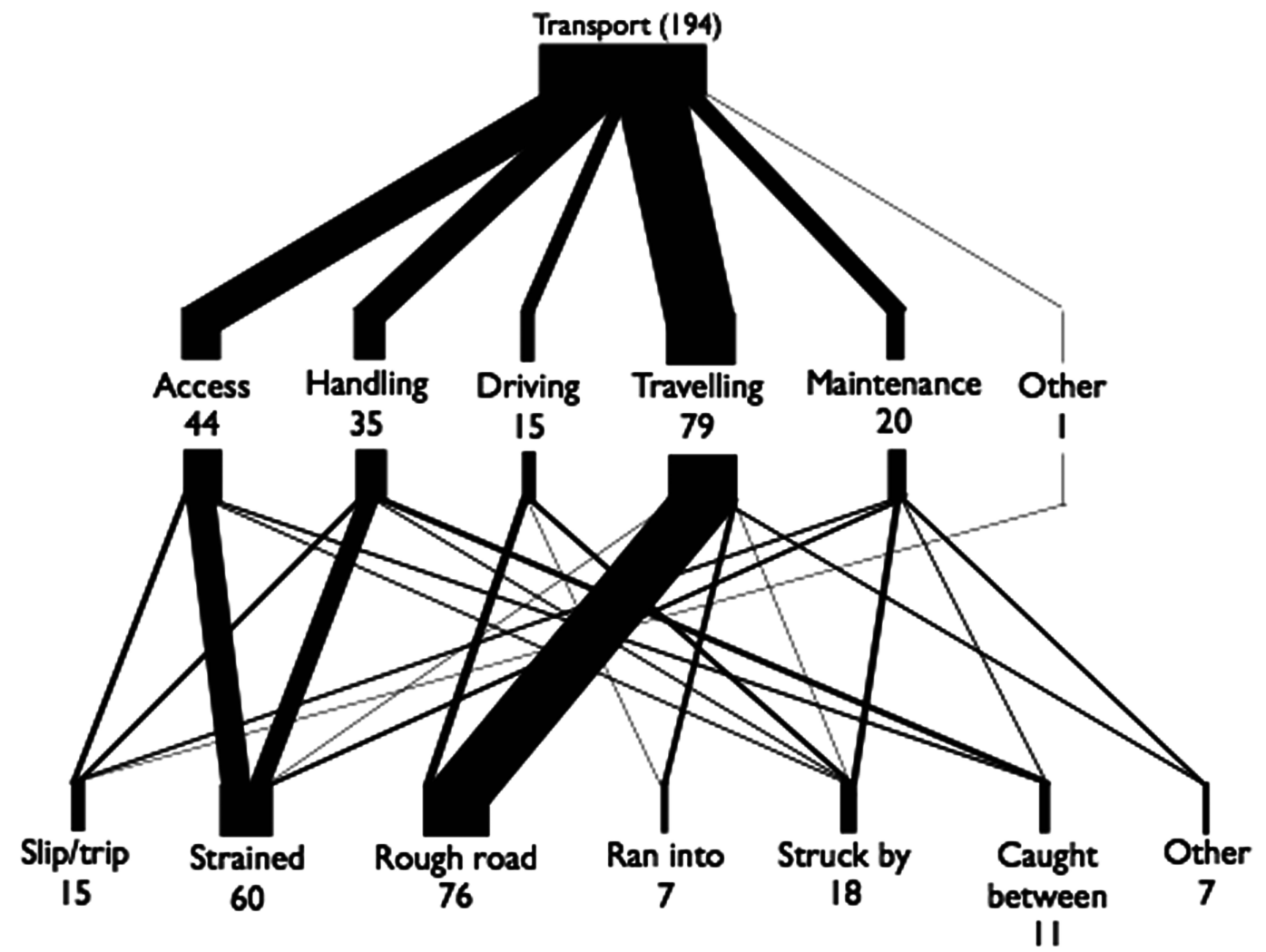

Fig. (4). Underground injury frequency by Activity and Mechanism associated with Personnel transport for NSW mines during the 3 years to June 30, 2008. 
Table 8. Underground Injury Frequency by Activity and Mechanism Associated with Personnel Transport

\begin{tabular}{|c|c|c|c|c|c|c|c|c|}
\hline & Caught Between & Ran into & Rough Road & Slip/Trip & Strain & Struck by & Other & Total \\
\hline Access & 3 & 0 & 0 & 6 & 33 & 2 & 0 & 44 \\
\hline Driving & 0 & 1 & 9 & 0 & 0 & 5 & 0 & 15 \\
\hline Handling & 6 & 0 & 0 & 5 & 22 & 2 & 0 & 35 \\
\hline Maintenance & 2 & 0 & 0 & 3 & 4 & 7 & 4 & 20 \\
\hline Travelling & 0 & 6 & 67 & 0 & 1 & 2 & 3 & 79 \\
\hline Other & 0 & 0 & 0 & 1 & 0 & 0 & 0 & 1 \\
\hline Total & 11 & 7 & 76 & 15 & 60 & 18 & 7 & 194 \\
\hline
\end{tabular}

Table 9. Example Injury Narratives for the Most Frequent Combinations of Activity and Mechanism Associated with Personnel Transport

\begin{tabular}{|l|l|}
\hline Activity and Mechanism & \multicolumn{1}{c|}{ Example Narratives } \\
\hline \hline Travelling: Rough road & $\begin{array}{l}\text { While travelling from panel to pit bottom sitting in the back of PJB hit rough roads \& was thrown in the air landing on his } \\
\text { tailbone on edge of seat fracturing his sacrum } \\
\text { While travelling in an overcrowded SMV sitting awkwardly the SMV jolted over numerous potholes causing pain in his } \\
\text { L/buttock \& lower back - lumbar disc injury } \\
\text { While sitting in PJB travelling to pit bottom along 642 travelling road hit a large bump launching him into the roof then back } \\
\text { down jarring neck \& lower back }\end{array}$ \\
\hline Access: Strain & $\begin{array}{l}\text { While mounting the rear of SMV he dislocated his R/knee } \\
\text { After alighting from rear of SMV he twisted his } \mathrm{L} / \mathrm{knee} \text { on uneven floor of road causing strain }\end{array}$ \\
\hline
\end{tabular}

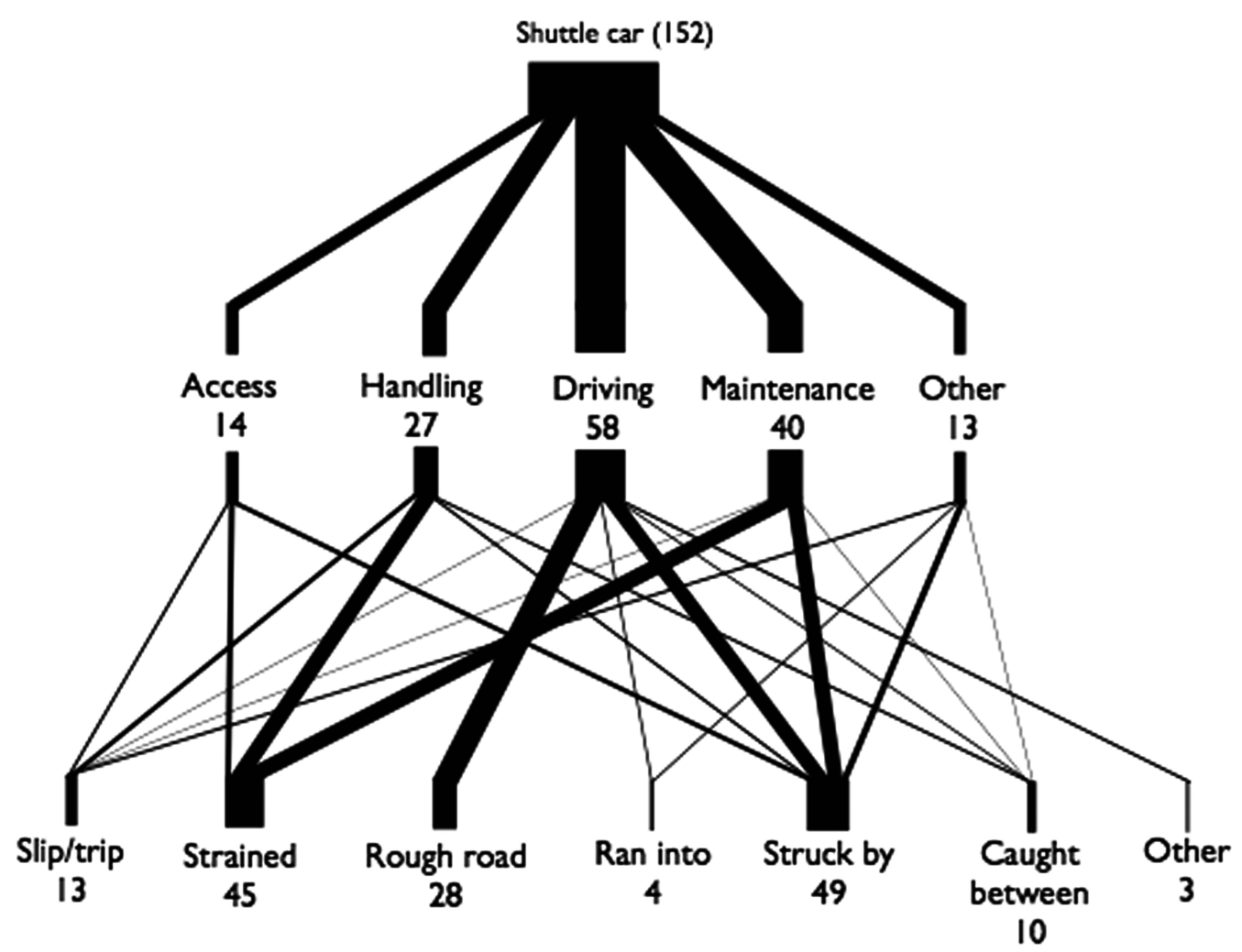

Fig. (5). Underground injury frequency by Activity and Mechanism associated with Shuttle cars for NSW mines during the 3 years to June 30, 2008. 
Table 10. Underground Injury Frequency by Activity and Mechanism Associated with Shuttle Cars

\begin{tabular}{|c|c|c|c|c|c|c|c|c|}
\hline & Caught Between & Ran into & Rough Road & Slip/Trip & Strain & Struck by & Other & Total \\
\hline Access & 0 & 0 & 0 & 3 & 6 & 5 & 0 & 14 \\
\hline Driving & 4 & 2 & 28 & 1 & 3 & 17 & 3 & 58 \\
\hline Handling & 1 & 0 & 0 & 5 & 18 & 3 & 0 & 27 \\
\hline Maintenance & 4 & 0 & 0 & 1 & 18 & 17 & 0 & 40 \\
\hline Other & 1 & 2 & 0 & 3 & 0 & 7 & 0 & 13 \\
\hline Total & 10 & 4 & 28 & 13 & 45 & 49 & 3 & 152 \\
\hline
\end{tabular}

Table 11. Example Injury Narratives for the Most Frequent Combinations of Activity and Mechanism Associated with Personnel Transport

\begin{tabular}{|l|l|}
\hline Activity and Mechanism & \multicolumn{1}{c|}{ Example Narratives } \\
\hline \hline Driving: Rough road & $\begin{array}{l}\text { While operating shuttle car he hit a bump on road causing him to hit head on roller bar spraining his neck } \\
\text { While driving shuttle car travelling along haulage road constant jarring of back on bumpy roads he felt lower back pain }\end{array}$ \\
\hline Driving: Struck by & $\begin{array}{l}\text { While sitting in shuttle car drivers cab a piece of stone came out of boom on c/miner into the s/car striking his chest and } \\
\text { throwing him out of the cabin causing bruising and pain } \\
\text { While driving s/car along wheeling road in low roof area because of rib spall he hit his head on a roof bolt causing neck pain }\end{array}$ \\
\hline Maintenance: Strain & $\begin{array}{l}\text { While bending to change a shuttle car tyre he strained his upper back } \\
\text { While working on a S/car replacing bearings in drivers side steering arm he was applying force to the seized parts in a } \\
\text { confined space he experienced pain to his lower abdomen }\end{array}$ \\
\hline
\end{tabular}

In a six week period in 1994, three operators of roofbolting machines in the USA were killed. Two were crushed between drill head and machine frame while rib bolting, the third crushed between drill head and canopy. A "Coal Mine Safety and Health Roof-Bolting-Machine Committee" was formed by MSHA to investigate, and a report released [20] which determined the causes to be unintentional operation of controls. The solutions proposed in this report were: 1 . Twohanded fast feed; 2 . drill head raise shutoff; 3. auxiliary controls; 4. guarding; 5 . pinch point identification; 6 . selfcentering controls; 7. hands-off drilling; 8 . insertion/retrieval devices; 9. standardised control layouts; 10 . pre-operational inspection. Other suggestions included in this report included: "Provide industry-wide accepted distinct and consistent knob shapes and relative handle lengths to identify corresponding control function" and "Standardize machine control lever movement and corresponding machine function movement." MSHA subsequently called for industry comment on an advance notice of proposed rulemaking titled "Safety standards for the use of roof-bolting machines in underground mines" [21] however no related rule or design criteria were subsequently released.

While bolting machines were not associated with any fatalities in NSW during the time period under examination, an incident did occur in which a drill bit was rotated whilst caught on mesh and a mine workers arm became entangled in the mesh, and subsequently amputated [22]. It is likely that the injured miner intended to adjust the position of the drill steel, but selected the adjacent rotation control (a selection error).
It is clear from the injuries reported by NSW mines in the three years to June 2008 that the design shortcomings previously identified in the context of bolting machines also remain to some extent in the design of controls on the bolting machines, and integrated miner bolters which are predominantly employed in Australian mines. Bolting controls require guarding to prevent inadvertent operation (while still allowing access for intentional operation). Bolting machine controls should be standardised across manufacturers to an appropriate layout (and provide shape and length coding) to reduce the probability of operation of the wrong control. This standardisation must carefully consider direction compatibility principles to reduce the probability of operation of controls in the wrong direction [23]. Improvements to bolting machine design are required to guard pinch points and provide interlocks (eg., twohanded fast feed) to reduce the probability and consequences of intentional or unintentional control operation whilst the operator or other person is in a hazardous location.

These conclusions are consistent with a safety alert issued in 2005 by the NSW Department of Primary Industries [24] which noted serious injuries occurring as a consequence of unintentional and intentional bolting control activation and recommended that roof and rib bolting systems should comply "as far as practical" with AS4024.1 "Safeguarding of machinery - General principles". The safety alert included the following as potential control measures: two handed control for fast speed operation; minimisation of pinch points; guarding to reduce inadvertent operation; shape coding; and standardised control layouts. 
These measures, including specified shapes for primary bolting controls, are also included in a revision of a Mining Design Guide addressing the design of bolting equipment [25]. Manufacturers of bolting equipment have responded to the revised Mining Design Guide for bolting equipment and these features are being incorporated in new equipment. While these design improvements may be expected to have some benefits, the implementation of automated bolting will be the most effective way of reducing these injury risks.

Drivers and passengers in vehicles in NSW underground coal mines suffered 173 injuries in the three years to June 2008 as a consequence of the vehicle encountering potholes or other roadway abnormalities. These injuries highlight the importance of maintaining roadway standards, because control at this level is most likely to be effective. Provision of vehicle suspension for shuttle cars, and improved seating in all vehicles [26-28], has potential to reduce the likelihood of these acute injuries. These improvements will also reduce exposure to whole body vibration, which is strongly associated with the development of back pain [29].

A further cause for concern is the number of potentially high consequence events involving being struck by hydraulic fluid. Extremely serious injuries, or even fatalities, can arise from being struck by hydraulic fluid under high pressure. The equipment involved included longwall; continuous miner \& bolting machine; and LHD. Improvements in equipment design to reduce the risks of hydraulic fluid injection was the aim of Mining Design Guide 41 which was revised in 2006 [30]. While manufacturers are adopting the requirements of this standard, other potential design improvements being implemented are the replacement of hydraulic hosing with piping where ever possible, and removing miners from proximity to hydraulic hoses.

Rare, but high potential consequence events reported during the period included interactions between personnel and mobile equipment such as continuous miners, LHD, and shuttle car; and transport equipment collisions. Many items of underground mobile equipment provide limited visibility for the operator, and improvements to equipment design to reduce these limitations have been proposed [31]. The use of video cameras has also been proposed [32], and are being implemented, particularly in large vehicles such as chock carriers.

Proximity detection systems have also been highlighted as a potential control measure to reduce the risk of interactions between pedestrians and mobile equipment, and between mobile equipment [33]. A continuous miner operator was crushed against the rib by a shuttle car at a Queensland mine in 2007, and died as a consequence. The coronial inquest [34] canvassed a number of issues related to the design of the equipment which may have contributed to the incident, and the recommendations made by the coroner included the future use of proximity detection.

The explosion risks associated with underground coal mines create additional barriers to the adoption of such technologies, and at the time of writing, there is no system currently certified for use in underground coal mines in Australia. While, proximity detection, especially if interlocked with vehicle controls, has potential to reduce pedestrian - mobile equipment interaction injury risks, greater reductions will be achieved by removing people from the vicinity of the equipment, and particularly the area around the continuous mining machine. These machine are currently remotely controlled, however the operator holding the remote does so via direct line-of-sight, standing adjacent to the equipment. Non-line-of sight remote control of the continuous miner is achievable in the short term (and has been undertaken as a control measure for when mining in outburst conditions) especially if combined with automated bolting. Fully automating the continuous miner is the next step. Efforts to achieve this have been underway for considerable time [35-37] and remains the aim of substantial current research [38].

\section{CONCLUSION}

Analysis of narratives describing equipment related injuries occurring in underground coal mines was an effective way of identifying high frequency combinations of equipment, activity and injury mechanism. Rare, but potentially high consequence events were also identified. The analysis provided valuable information for identifying opportunities for reducing injury risks associated with underground coal mining equipment. Potential short term controls include: monorails for continuous miner services; redesign of continuous miner platforms and bolting rigs to reduce reach distances during drilling and bolting; improvements to guarding of bolting controls; standardisation and shape coding of bolting controls; two handed fast-feed; improvements in underground roadway maintenance, vehicle suspension, visibility and seating; and proximity detection devices interlocked with mobile equipment controls. Longer term control measures include automated bolting, and mesh placement, in conjunction with either non-line-of-sight remote control of, or automated, continuous mining machines.

\section{ACKNOWLEDGEMENT}

The research was supported by the Australian Coal Association Research Program (grant C18012).

\section{CONFLICT OF INTEREST}

\author{
None declared.
}

\section{REFERENCES}

[1] Poplin GS, Miller HB, Ranger-Moore J, et al. International comparison of injury rates in coal mining: A comparison of risk and compliance-based regulatory approaches. Saf Sci 2008; 46: 1196-204.

[2] NOHSC. National workers compensation statistics data base 2005; http://nosi2.nohsc.gov.au/

[3] Burgess-Limerick R, Steiner L. injuries associated with continuous miners, shuttle cars, load-haul-dump, and personnel transport in New South Wales underground coal mines. Mining Technol (TIMM A) 2006; 115: 160-8.

[4] Helander MG, Krohn GS. Human factors analysis of underground metal and nonmetal mines. USBM report 1983; PB84-158732

[5] Helander MG, Krohn GS, Curtin R. Safety of roof-bolting operations in underground coal mines. J Occup Accid 1983; 5: 16175.

[6] Bondy J, Lipscomb H, Guarini K, Glazner JE. Methods for using narrative text from injury reports to identify factors contributing to construction injury. Am J Ind Med 2005; 48: 373-80.

[7] Lipscomb HJ, Glazner J, Bondy J, Lezotte D, Guarini K. Analysis of text from injury reports improves understanding of construction falls. J Occup Environ Med 2004; 46: 1166-73. 
[8] Lipscomb HJ., Glazner JE, Bondy J, Guarini K, Lezotte D. Injuries from slips and trips in construction. Appl Ergon 2006; 37: 267-74.

[9] Lombardi DA, Pannala R, Sorock GS, et al. Welding related occupational eye injuries: a narrative analysis. Injury Prev 2005; 11: 174-9.

[10] Shibuya H, Cleal B, Kines P. Hazard scenarios of truck drivers' occupational accidents on and around trucks during loading and unloading. Accid Anal Prev 2010; 42: 19-29.

[11] Gallagher S, Hamrick CA, Cornelius KM, Redfern MS. The effects of restricted workspace on lumbar spine loading. Occup Ergon 2001; 2: 201-13.

[12] Porter I, Van Duin S. C17018 continuous miner mounted, fully automated system for installing self drilling bolts and steel mesh for primary roof and rib support during roadway development. Australian Coal Association Research Program. Current projects May 2009-July 2009. p. 14.

[13] Lukey C, Baafi E. C17004 Tough skin for strata control. p. 19. Australian Coal Association Research Program. Current projects May 2009-July 2009. p. 14

[14] Hedling WG, Folley JD, Jr. Standardization of continuous miner control configurations. USBM Report 1972; OFR 25-72.

[15] Grayson RL, Layne LA, Althouse RC, Klishis MJ. Risk indices for roof bolter injuries. Min Eng 1992; 44: 164-6.

[16] Helander MG, Conway EJ, Elliott W, Curtin R. Standardization of controls for roof bolter machines. Phase 1. Hum Fact Eng Anal 1980; USBM OFR 170-82 PB83-119149.

[17] Klishis MJ, Althouse RC, Stobbe TJ, et al. Coal mine injury analysis: a model for reduction through training. Volume VIII Accident risks during the roof bolting cycle: analysis of problems and potential solutions. 1993; USBM Cooperative agreements C0167023 \& C0178052.

[18] Muldoon TL, Ruggieri S, Gore T, McDonald LB. Design and develop standardized controls in roof bolting machines preliminary design. USBM OFR 107-80, 1980.

[19] Burgess-Limerick R, Krupenia V, Zupanc C, Wallis G, Steiner L. Reducing control selection errors associated with underground bolting equipment. Appl Ergon 2010; 41: 549-55.

[20] MSHA. Coal mine safety and health roof-bolting-machine committee. Report of Findings July 8, 1994.

[21] MSHA. Safety standards for the use of roof-bolting machines in underground coal mines. Advance notice of proposed rulemaking. Federal Register: Dec 9, 1997; vol. 62(236), pp. 64789-790. Available at: www.msha.gov/REGS/FEDREG/PROPOSED/1997PRO P/97- 32203.HTM accessed 12/14/2005

[22] NSW DPI. Summary Investigation Report: Serious injury involving roof bolter at AUSTAR COAL MINE on 3 March 2008. NSW Department of Primary Industries.
[23] Burgess-Limerick R, Krupenia V, Wallis G, Pratim-Bannerjee A, Steiner L. Directional control-response relationships for mining equipment. Ergonomics 2010; 53: 748-57.

[24] NSW DPI. Safety alert: drill rigs and serious injuries. mine safety report number SA05 - 05. NSW Department of Primary Industries 2005.

[25] NSW DPI. Guideline for bolting \& drilling plant in mines. Mining Design Guideline 35.1. NSW Department of Primary Industries 2009.

[26] Grant D, Dayawansa D, Curcio P. Confronting a real underground safety issue -Improving safety and comfort in underground personnel transport. In: Proceedings of the Queensland Mining Industry Health and Safety Conference, Townsville 2005.

[27] Mayton AG, Gallagher S, Merkel R. Ergonomic seat with viscoelastic foam reduces shock on underground mobile equipment. Advances in occupational ergonomics and safety. IOS Press II 1997; pp. 177-80.

[28] Mayton AG, Merkel R, Gallagher S. improved seat reduces jarring/jolting for operators of low-coal shuttle cars. Min Eng 1999; 51: 52-6.

[29] McPhee B, Foster G, Long A. Bad vibrations. $2^{\text {nd }}$ ed. Coal Services Health and Safety Trust 2009 .

[30] NSW DPI. Guideline for fluid power system safety at mines Mining Design Guide 41. NSW Department of Primary Industries 2006.

[31] Eger T, Salmoni A, Whissell R. Factors influencing load-hauldump operator line of sight in underground mining. Appl Ergon 2004; 35: 93-103.

[32] Godwin A, Eger T. Using virtual computer analysis to evaluate the potential use of a camera intervention on industrial machines with line-of-sight impairments. Int J Ind Ergon 2009; 39: 146-51.

[33] Rasche T. Too close for comfort: The case for proximity detection systems. Proceedings of the 2009 Queensland Mining Safety Conference. Townsville 2009.

[34] Hennessy A. Inquest into the death of Jason George Elliott Blee. Office of the State Coroner (Queensland) 2009.

[35] Shaffer G, Stentz A. A robotic system for underground coal mining. In: Proceedings of the 1992 IEEE International Conference of Robotics and Automation. Nice, France 1992.

[36] Schnakenberg GH. Progress toward a reduced exposure mining system. Min Eng 1997; 49: 73-7.

[37] Huang H-M, Horst J, Quintero R. A motion control algorithm for a continuous mining machine based on a hierarchical Real-time Control System design methodology. J Intell Robot Syst 2004; 5: 79-99.

[38] Reid D. C18023 CM2010 project - Continuous miner automation component. Current projects May 2009-July 2009. p. 15. Australian Coal Association Research Program 2009.

This is an open access article licensed under the terms of the Creative Commons Attribution Non-Commercial License (http: //creativecommons.org/licenses/ by-nc/3.0/) which permits unrestricted, non-commercial use, distribution and reproduction in any medium, provided the work is properly cited. 